\title{
RELIGIOUS FUNDAMENTALISM IN SOUTH AFRICA
}

\author{
David Chidester \\ Department of Religious Studies \\ University of Cape Town
}

\begin{abstract}
Against the background of defining, theorizing, humanizing, nationalizing, and globalizing religion in South Africa, this essay recalls the diverse ways in which religious fundamentalism has registered in South Africa as an 'inauthentic' claim on religious authenticity. Tracking academic and media attention to religious fundamentalism at ten-year intervals, we find Christian fundamentalism appearing during the 1970s as contrary to the apartheid state, during the 1980s as legitimating the apartheid state, and during the 1990s as resisting the new democratic dispensation. By the 1990s, however, attention to religious fundamentalism, locally and globally, shifted to focus on varieties of politicized Islam. As this brief historical review suggests, the term, 'fundamentalism,' whether applied to Jesus People in Johannesburg during the 1970s or People Against Gangsterism and Drugs during the 1990s, has been a recurring but shifting sign of a crisis of authenticity. In conclusion, South African perspectives on religion, the state, and authenticity can be drawn into analyzing the current crisis of fundamentalism in our rapidly globalizing and increasingly polarized world.
\end{abstract}

Keywords: Authenticity, Fundamentalism, Globalization, Religion and State, South Africa

Religious fundamentalism is a problem. It is a definitional problem. What is it? An eminent scholar of religion, Scott Appleby, questions the viability and transferability of the term, putting it in 'scare quotes,' or rendering it as 'strong religion,' but nevertheless he finds that religious fundamentalists in any religious tradition display certain characteristic features, tending to be reactive, selective, absolutist, dualistic, and millenarian in their expectations of the imminent destruction of the prevailing social order (Sherman, 2005; see Appleby 2000). But fundamentalism is also a normative problem. Why should we be worried about it? As many analysts and critics have argued, we must be worried about religious fundamentalism because it violates the moral order of modernity by its irrational violence and intolerance, its puritanical mores and patriarchal gender discrimination, which deploy premodern religious impulses to challenge modern social formations.

My concern, here, is to think about how we understand and worry about religious fundamentalism in South Africa. The vast literature on religious fundamentalism, now global in scope, has influenced our understanding, just as an increasingly polarized geopolitics has affected our worries. But our specific location and history in South Africa provides a distinctive perspective on the definitional and normative problems raised by religious fundamentalism.

In what follows, I want to explore these problems by asking what I regard as fundamental questions. First, I want to ask: How does our location in South Africa, with our particular history, inform the ways in which we might understand religion? Briefly, testifying to my own experience, I will touch on some of the ways in which being in South 
Africa has taught me about the problems and prospects for dealing with defining, theorizing, humanizing, nationalizing, and globalizing religion.

Second, focusing specifically on that variety or variation of religion that has been called 'fundamentalism,' I want to ask: How has religious fundamentalism appeared in South Africa? Going back through our recent history, beginning in the 1970s, I find recurring popular and academic interest in 'fundamentalism' as a highly-charged term for a crisis. From the 1970 s, as I will recall, every decade has seen a crisis of fundamentalism but every crisis has been dramatically different. In other words, South Africans have had a longstanding historical engagement with religious fundamentalism, but fundamentalism has never been the same thing in this history.

Third, here and now, I want to ask: Why are we currently worrying about religious fundamentalism? Why are we even talking about fundamentalism now? If we are going to talk about fundamentalism, how should we understand religious fundamentalism, from a South African perspective, in our current situation, locally and globally? As a prelude to wrestling with these questions, I review briefly a situated South African history of thinking about religion and engaging religious fundamentalism.

\section{Thinking about Religion in South Africa}

South Africa is a multi-religious country. Although over 70 percent of South Africans claim allegiance to Christianity, South Africa is home for a variety of religious traditions - indigenous African, Muslim, Jewish, Hindu, Buddhist, and others - that have established strong, vital constituencies. With a deep and enduring African religious heritage, South Africa is a country that embraces all of the major 'world religions.' Each of these religions, including Christianity, is a diverse category, encompassing many different understandings of religious life. At the same time, many South Africans draw their understanding of the world, ethical principles, and human values from sources independent of religious institutions. In the most profound matters of life orientation, diversity is a fact of South African national life.

Given the diversity of language, culture, and religion in South Africa, the post-apartheid government of South Africa, which came to office after the first democratic elections of 1994, has sought ways to turn diversity from a potential obstacle to nationalism into a national resource, seeking not uniformity but unity, as the new Coat of Arms urges: Diverse people unite. Endeavouring to come to terms with the legacy of apartheid, the South African government has worked to find new ways of transforming the vicious divisions of the past into the vital diversity of a free, open, and democratic society.

For more than twenty years, I have found South Africa to be a particularly fruitful place to study religion. I have learned a lot just by being here. Quickly, let me identify five things this place has taught me:

- First, South Africa has taught me about the politics of defining religion. Here I learned that religion has always been an inherently oppositional term. The ancient Latin, religio, was defined in opposition to superstitio. The modern, religion, has been defined as a colonial opposition to 'superstition' or a contemporary opposition to 'cults.' From a South African perspective, our keyword, 'religion,' did not come from Greco-Roman antiquity or the European Enlightenment. It came from the sea in ships. It was carried by European travelers, missionaries, and colonial administrators, who first deployed it as an instrument of denial, reporting that Africans had no religion, but it was eventually deployed as an instrument of colonial containment, making a 'religious system' the 
spiritual supplement to the colonial magisterial system, location system, or reserve system for keeping people in place (Chidester, 1996).

- Second, South Africa has taught me about the history of theorizing religion, the cultural, social, and political history of theorizing religion. In graduate school, I learned that my academic discipline had a founder, F Max Müller, whose 1870 lectures in London on the science of religion inaugurated an academic study of religion. Of course, I also learned that everything he said was wrong, but at least I had a founding ancestor in an ancestral lineage that included other late-Victorian British intellectuals, such as EB Tylor, Andrew Lang, and James Frazer. Re-reading their work in South Africa, I realized they were not just talking about religion; they were talking about us. Their theorizing about the original, 'primitive,' religion was directly related to British imperial ambitions and colonial adventures in South Africa (Chidester, 2004).

- Third, South Africa has taught me about the human dynamics of the inherent ambivalence of religion. However the term might be defined or theorized, religion is a truly ambivalent human enterprise - legitimating oppression, mobilizing liberation. As both the best and the worst, as both humanizing and dehumanizing, religion is a domain of inclusion and exclusion. During the 1980s, I learned about this ambivalence as much from Oliver Tambo as from Desmond Tutu. While the Archbishop, in the name of God, was urging for the human recognition of ubuntu, the president in exile of the African National Congress was analyzing the religiopolitical terrain in apartheid South Africa in which the human was poised between the superhuman claims of the apartheid state and the dehumanization suffered by the majority of the people in South Africa within a capitalist economy (Chidester, 1992:17).

- Fourth, since 1994, South Africa has taught me about the potential (and limitations) of religion in nation-building. Adopting a 'co-operative model' for relations between religion and state, the new constitutional order did not create a 'wall of separation' that cordoned off a privatized religion from the public sphere. Rather, in keeping with the national motto, 'unity in diversity,' the post-apartheid state has tried to draw upon the resources of the many religions of the country in the national interest. For example, during a busy weekend in September 2003 visiting religious communities, including the Jewish Board of Deputies, a new Hindu organization, and the Zionist Christian Church, President Thabo Mbeki observed: "Given our divided history, religious organizations have an important role to play in the reconstruction and development of our country, especially in the welfare and civil society sectors" (Anonymous, 2003).

While seeking to mobilize all the religious constituencies of the country, the post-apartheid state has also implemented a new policy for teaching and learning about religion, religions, and religious diversity, which Minister of Education Naledi Pandor recently called 'an exciting and distinctively South African response to an educational challenge faced by our society.'

Our educational policy recognises the difference between religious, theological, or confessional interests, and the educational objectives of Religion Education. While respecting religious interests and valuing religious contributions to our country, the policy charts a course for our schools to make their own, distinctive contribution to teaching and learning about religion in ways that will celebrate our diversity and affirm our national unity (Pandor, 2005; see Chidester, 2003). 
Certainly, these national projects - harnessing the potential of religion, limiting discrimination on the basis of religion, expanding the scope of mutual human recognition and understanding in the midst of religious difference - are difficult (and problematic), but they grow out of an admirable willingness to take religion seriously.

- Fifth, South Africa has taught me about globalization, as both a description of a changing culture and a changing culture of description, which has altered the terrain for thinking about religion. In my recent research, I have been interested in two problems:

What happens when the 'indigenous,' intimately grounded in a specific place, goes global? The Zulu witchdoctor, sangoma, sanusi, and now shaman Credo Mutwa, for example, who has been described in our popular press as a 'fake, fraud, and charlatan,' has emerged in the global circuit of neo-shamanism as the bedrock of African indigenous authenticity to underwrite a variety of projects, including New Age spirituality, alternative healing, crime prevention, business management, environmentalism, and encounters with aliens from outer space, not to mention the work of conspiracy theorist David Icke (Chidester, 2002).

What happens when the 'global,' crossing boundaries, makes claims on our place? Afrika Bambaataa, for example, the African-American godfather of Hip Hop, whose group, Zulu Nation, was not African, Zulu, or a nation, nevertheless moved into our space to identify two kinds of religion: On the one side, Afrika Bambaataa identified the 'go to sleep slavery type of religion,' the religion of the dream, the religion of the oppressed that sealed their oppression. On the other side, there was the 'spiritual wake up, revolutionary,' religion of conscious, positive action, 'like the prophets,' in which 'knowledge, wisdom, [and] understanding of self and others' inform a 'do for self and others type of religion' (Chidester, 2005:230-31).

These examples raise the question of authenticity. Which is more true to our experience: the commodified religious export or the revolutionary religious expert? Now that Oprah Winfrey, through DNA testing, has discovered her Zulu roots, this question of authenticity - locally, globally - will perhaps be clarified (BBC, 2005). In the meantime, we dwell in the dilemma of authenticity.

\section{Engaging Religious Fundamentalism in South Africa}

In popular media and academic analysis, religious 'fundamentalism' has often been cast as a form of religion that makes inauthentic claims on religious authenticity. But religious fundamentalism has also signaled a crisis. In South Africa, we have worried about fundamentalism since the 1970 s, but we have not been worrying about the same thing from decade to decade. I will quickly review these different engagements with fundamentalism in South Africa. Recalling these engagements at ten-year intervals, we will find Christian 'fundamentalism' appearing during the 1970s as contrary to the apartheid state, during the 1980 s as legitimating the apartheid state, and during the 1990s as resisting the new democratic dispensation. By the 1990s, however, attention to religious 'fundamentalism,' locally and globally, shifted to focus on varieties of politicized Islam. As this brief review suggests, the term, 'fundamentalism,' has been a recurring but shifting sign of a crisis of authenticity. 


\section{0s: Jesus People in Johannesburg}

In the earliest research that I can find on religious fundamentalism in South Africa, Christopher R Stones published a series of articles in the 1970s based on his investigation of 'Jesus People' in Johannesburg (Stones, 1977; 1978a; 1978b). These fundamentalist or 'born again' Christians studied by Stones were white, English-speaking, and living communally. Explicitly identifying the members of this Christian community as fundamentalists, Stones utilized two research instruments - the Brown and Lowe Inventory of Religious Belief (1951) and the Wilson and Patterson Conservative Scale (1968) - to test the hypothesis that religious fundamentalism should correlate with social conservatism.

Since the results of this research might be surprising, I will move immediately to Stones's finding that these religious fundamentalists, who tested high for religious belief, scored very low on the socially conservative scale, being less conservative, less militaristic, less racially prejudiced, and less opposed to pleasure - less 'anti-hedonistic' - than their peers in their social environment. Measured against a 'control group,' these religious fundamentalists were found to be less socially conservative than other young white people in Johannesburg.

The research instruments that Christopher Stones used to arrive at this conclusion are worthy of mention. The Brown and Lowe Inventory of Religious Belief, formulated in 1951, provided a set of fifteen questions, with each question weighted on a five-point 'Likert-type scale,' in order to differentiate between those who accept and those who reject the literal truth of Christianity. So, an instrument for measuring religious belief developed in the early 1950s, in post-war, Cold War America, was applied in Johannesburg. Even a quick glance at the questions posed by the Brown and Lowe Inventory of Religious Belief must make us wonder if this research instrument is already weighted for polarization. For example, just asking about the Bible, the inventory asks research subjects to agree or disagree with dramatically polarized propositions. On the one hand, a subject might agree with the proposal, 'I believe the Bible is the inspired Word of God.' If so, the subject would be assenting to a 'positively keyed item' for religious fundamentalism. On the other hand, a subject might identify with the proposal that the 'Bible is full of errors, misconceptions, and contradictions.' Agreeing with this 'negatively keyed item' would place such a subject very low on the religious belief or religious fundamentalism scale.

The religious fundamentalists in Johannesburg scored high on all of the indicators of religious beliefs that were based on the authority of the Bible, basic Christian doctrines such as the Virgin Birth and the Second Coming, and even the exclusivity of Christian redemption in which they agreed that the 'gospel of Christ is the only way for mankind to be saved' and that 'eternal life is the gift of God only to those who believe in Jesus Christ as Saviour and Lord.' On the belief scale, therefore, these fundamentalists were committed to being faithful to the fundamentals of their religious tradition. Religiously, they were conservative. We might expect that they were also socially conservative. Here is where Christopher Stones, applying Wilson and Patterson's Conservatism Scale, which was developed in American during the turbulent year of 1968 instead of in the cold-war context of the early 1950s in which the religious belief measures were produced, found that these religious fundamentalists were less conservative than the white, English-speaking 'control group' living in Johannesburg.

During the $1970 \mathrm{~s}$, therefore, religious fundamentalists registered as a problem for academic research. As Christopher Stones found, conservative Christians, adhering to fundamental Christian doctrines, could be religiously conservative but socially liberal. Conservatism in religious belief, therefore, did not necessarily correlate with conservative 
political, social, or economic positions within the prevailing social order. However, the prevailing order, under the apartheid regime of the National Party in South Africa, was enforcing a radically conservative programme of militarism, racism, and denial of human freedom and expression. As Christopher Stones observed, the religious fundamentalists that he studied ran up against this conservative order. Christian fundamentalists, he found, were less militaristic, less racially prejudiced, and less repressive of personal pleasure and freedom of expression.

But these religious fundamentalists might also have registered as a threat to the apartheid state because their commitment to fundamental Christian doctrines, which were also proclaimed by the National Party regime, in church and state, did not correlate with the conservative policies of militarization, racism, and discipline advanced by the state. So, the prevailing regime in South Africa might have found these religious fundamentalists dangerous because they were not militaristic, racist, or intolerant.

Christopher Stones, reflecting on his research, points to the tension between these religious fundamentalists and their increasingly militarized social context in apartheid South Africa. 'It is interesting,' he observes, 'that members of the Jesus movement should have become significantly less militaristic at a time when South African mainstream ethos is one of increasing militarism' (Stones, 1978a:157). Reflecting, again, on context, Christopher Stones noted that 'relative to their cultural milieu, the Jesus people have become less racially prejudiced' (Stones, 1978a:157). They were also, he found, more secure, more flexible, and more tolerant of change.

I dwell on these research findings for their striking contrast with current formulations of religious fundamentalists as militant, violent terrorists; as intolerant, as puritanical. During the 1970s, religious fundamentalists in Johannesburg were a 'problem' because they were less militant, less racist, and less puritanical than they should have been according to the ethos of the apartheid regime. In this context, religious fundamentalists posed a problem for both research and governance because they seemed to be more secure, more tolerant, and perhaps even happier than they should be. Clearly, for the militarized and racist apartheid regime, if these religious fundamentalists, as Christopher Stones found, were 'less militaristic' and 'less racially prejudiced,' then they represented an implicit challenge to the militarized and racist order of the state in South Africa. Accordingly, religious fundamentalists represented a crisis not because they were violent and exclusive but because they were non-violent and tolerant of diversity.

\section{0s: Fundamentalism and the Apartheid State}

During the mid-1980s, popular and academic interest in religious fundamentalism focused on right-wing Christians, often coming from the United States, who were providing ideological legitimation for the apartheid state. Here, unlike the Jesus People in Johannesburg, religious conservatism clearly correlated with a conservative moral, social, and political agenda. Taking Protestant fundamentalism into the political arena in the United States, Jerry Falwell had founded a national organization, the Moral Majority, which was dedicated to achieving conservative political goals in four areas: pro-life, pro-family, promoral, and pro-American. Falwell's conservative Christian crusade defined the basic outlines of political policy advocated by the 'New Religious Right' or the 'New Christian Right' in the United States. That political policy was also a conservative Christian foreign policy that urged US support for the modern states of Israel, Taiwan, and South Africa.

In South Africa, the ideological support provided by right-wing Christians from the United States was welcomed by the National Party regime, which was attempting to 
maintain the apartheid system of racist oppression. As a frequent visitor during the 1980s, Jerry Falwell praised South Africa as a 'Christian country' in which human rights were upheld, that is, the rights of the unborn, because abortion was illegal. Defending the apartheid regime, Falwell castigated the Anglican archbishop Desmund Tutu as a 'phoney' (Gifford, 1991:35). According to one conservative Christian publication in the United States, the Family Protection Scoreboard, 'in the area of traditional family values, South Africa puts America to shame' because in South Africa there was no abortion, pornography, debates about women's rights, constitutional separation of church and state, or secular humanism, all of which had allegedly eroded Christian 'family values' in the United States. Conservative evangelist Jimmy Swaggert also praised South Africa as a 'godly country' on the front lines of the battle between the communist Antichrist and the 'Christian civilization' represented by the minority white regime (Chidester, 2000a:531).

In 1986 a group of 'concerned evangelicals' in Soweto objected to the fact that their "evangelical family had a track record of supporting and legitimating oppressive regimes here and elsewhere" (Concerned Evangelicals, 1986:4). The National Party regime in South Africa, however, welcomed the support from US evangelists and fundamentalists because the Dutch Reformed Church, which had been known as the 'National Party at prayer,' was no longer providing unconditional Christian justifications for the system of apartheid. A number of small right-wing Christian movements, such as the Gospel Defence League and Frontline Fellowship, emerged in the 1980s, drawing on evangelical or fundamentalist religious resources to defend the legitimacy of the apartheid state (Arendse, 1989; Gifford, 1988; Green, 1987).

While conservative Christians in South Africa could look to the New Religious Right in the United States to justify a Christian state, South African Muslims could draw inspiration from the Iranian Revolution of 1979 to imagine the possibility of an Islamic state (Lehmann, 2006). Qibla, founded in 1980 by Achmed Cassiem, advocated a dual struggle against the apartheid state and for the creation of an Islamic state in South Africa. Global in scope, this vision of an Islamic state embraced the term 'fundamentalism' as an empowering self-designation, aligning Qibla with "pro-Islamic fundamentalist countries in their attempts to establish an Islamic republic in South Africa based on the principles of the Sharia and the teachings of the Quran" (cited in Le Roux and Nel, 1998:7). Like Jerry Falwell, therefore, Achmed Cassiem used the term 'fundamentalism' at the nexus of religious conservatism, adhering to the fundamental authority of a canonical text, and a moral, social, and political programme for creating a religious state. During the 1980s, however, while Christian fundamentalism was gaining international attention, the Muslim fundamentalism advanced by Qibla received relatively little notice in the popular media or academic analysis in South Africa (but see Essack 1988; Rice 1987). That would change after the democratic elections for a new South Africa in 1994.

\section{0s: Fundamentalism in the Streets and Schools}

Perhaps we forget that the 1994 election campaign was saturated with religion. In the prelude to the 1994 election, campaign advertising evoked all the competing claims on sacred authority and power that remain an undercurrent beneath the dominant imagery of a unified 'New South Africa.' Often these advertisements displayed explicit religious content. For example, the ANC issued a full-page advertisement, supported by signatures of Christian clergy, proclaiming the gospel as the only framework for establishing full political inclusion and guaranteeing social justice. The National Party, with an ad campaign based on the testimony of ordinary people, occasionally played the religious theme. One 
advertisement quoted the Reverend Macfarlane Phenethi: "The NP apologized. As a Christian I accept that. The NP is now the party for me." Christian justice, Christian mercy - the call for Christian commitment was a significant feature of campaign rhetoric: The African Christian Democratic Party, declaring that "It's time to do it God's way," asserted that it was the only party that could unify the nation because it upheld Christian principles as the foundation for a just society. The right-wing Freedom Front claimed to represent the interests of concerned Christians in defending Christian values against the evils of communism. The Inkatha Freedom Party, however, must receive the award for creative Christian advertising. During its one-week campaign for the election, Inkatha advertised a mixed message that fused its last-minute entry into the campaign, and its ad-hoc position at the bottom of the ballot paper, into a single biblical promise of apocalyptic redemption by invoking Matthew 20:16 - "So the last shall be first."

Although Christian themes were prominent in campaign advertising, they were in counterpoint with competing Muslim claims to religious authority. In the weekend papers prior to the election, Qibla placed an add that juxtaposed the Qur'anic injunction - "Let there be no hostility except against those who practice oppression" - with a photograph of Mandela and De Klerk clasping hands, to urge people, 'Do not vote!' In the same newspaper, however, a two-page ad appeared for the African Muslim Party, calling the faithful, not only to vote, but to vote for the only party that represented Islamic law. Voters would be rewarded both in this life and the hereafter. In this life, the ad claimed, voters would be rewarded with a just society. In the hereafter, they would be saved from punishment for the sin of supporting any non-Muslim party that might extend civil rights to homosexuals. Like Christian advertising, this ad from the African Muslim Party made dramatic campaign promises of religious redemption.

Within the changing political landscape of post-apartheid South Africa, however, different Muslim claims began to be asserted in the streets of Cape Town. In July 1996, a new religious movement calling itself Pagad - People Against Gangsterism and Drugs marched on the home of a local drug-dealer, Rashaad Staagie, shot him dead, and set his body on fire in the street. As one leader declared, "We are going to take back the streets tonight" (Mail and Guardian 8 August 1996). Claiming to be an inter-religious organization, Pagad was clearly driven by a small group of Muslim leaders, with a very specific religious agenda, but the movement initially gained grassroots support from people who felt that their lives, families, homes, and communities were under threat from gangsters (Tayob, 1996).

As a distinctively urban religious movement, Pagad deployed not only compelling religious rhetoric but also rallies, marches, and processions through the streets of Cape Town. Allegedly, Pagad also utilized paramilitary techniques - armed guards, mobile defense units, pipe bombs, and assassinations - to advance its religious cause. Hundreds of attacks against suspected drug dealers, but also against Muslim critics, academics, former members, and public places, such as the Planet Hollywood bombing at the Waterfront, were generally attributed to Pagad but vigorously denied by the movement's leadership. By February 1999, President Nelson Mandela was compelled to address this movement, even if indirectly, since he never explicitly named Pagad, in a speech before parliament, observing that "what started off expressly as a campaign against gangsterism, has now become a violent and murderous offensive against ordinary citizens." Although portraying itself as "moral and god-inspired," President Mandela observed, this religious movement "has assumed the form of terrorism to undercut Cape Town's lifeline and destablise a democratic government' (Mandela, 1999). 
In the struggle over defining the religious meaning of urban space in Cape Town, however, Pagad had gained not only a considerable support base but also a certain purchase on setting the basic terms of engagement in the city. In response to the president's speech in parliament, Pagad issued a press statement that praised Nelson Mandela's political contribution to the struggle against apartheid but condemned his religious position. "He is using our churches, mosques, and synagogues," Pagad declared, "to try and gain support from religious leaders to back political parties that stand for ungodly laws such as abortion, prostitution, gay rights, etc." Insisting that in the spiritual politics of South Africa the personal is always political, Pagad attacked Nelson Mandela for being "the leader of a party that has consistently and deliberately violated the laws of God" (Chidester, 2000b:29). As this struggle over the city continued, Pagad persisted in defining Cape Town as the site of a moral drama, a conflict between the forces of good and evil, that was local, national, and international, with its international scope highlighted on the internet by the Pagad website that displayed the logo of the movement against the background of a Mercator projection of the entire globe. According to Pagad, therefore, the local neighbourhood in Cape Town was a microcosm of the world, a local battlefield on which a cosmic war was being waged between global forces of good and evil. As this conflict over the meaning of the local neighbourhood intensified at the end of the 1990s, the Muslim leadership of Pagad struggled to reposition Islam, or a certain version of Islam, from the periphery to the centre of the city.

Like the streets, the schools became a space for asserting fundamental religious claims. In response to the new curriculum, some Christians in South Africa, especially those with ideological, organizational, and financial links with conservative Christian groups in the United States, vigorously objected to the policy for religion education. Through an organized, coordinated campaign, they argued that the new policy violated their human rights and constitutional rights to freedom of religion. This campaign drew together apparently separate organizations - a Christian organization for home schooling (Pestalozzi Trust), a Christian organization for evangelizing Africa (Frontline Fellowship), a Christian political party (the African Christian Democratic Party), and other Christian groupings - in common cause against the new policy, curriculum, and learning outcomes.

As the most vocal opponents, Christian reconstructionists mobilized letter-writing campaigns, media events, and public meetings against the new policy. Culminating at a public meeting in the Western Cape at the Christian Centre on 9 October 2001, these opponents advanced the ingenious argument that teaching and learning about religion, religions, and religious diversity, which is an educational rather than a religious activity, was actually promoting a religious worldview. Summarizing the meeting of 'concerned Christians' at the Christian Centre, the reporter noted that the principal problem with the new policy was its "active promotion of a single set of values under the guise of tolerance" (Christian Centre, 2001). These values, which were glossed as relativism, situational ethics, and the equality of all religions, were castigated as the basic elements of a New Age religion. "This set of implicit values," the reporter declared, "is present in most New Age systems of thought. Teaching and assessment based on these values effectively constitutes state promotion of a religious worldview in itself (secular humanism). This is in total contradiction with the constitutional provision of freedom of religion." Although the promotion of relativism, situational ethics, and the religious equivalence of religions nowhere appears in the policy, 'concerned Christians' at this meeting could nevertheless discern the implicit traces of a religious worldview, the religion of 'secular humanism,' which was allegedly being established in public schools as an act of religious discrimination against Christians (Christian Centre, 2001). 
Although this campaign certainly drew in parents who were concerned about the direction of educational policy in South Africa, the ingenious argument that education about religion 'implicitly' promoted a religious worldview - the religion of secular humanism - was derived from right-wing Christian organizations in the United States. Insisting that 'secular humanism' has been defined as a religion by the U.S. Supreme Court, Christian opponents of the new educational policy in South Africa have been misled by right-wing Christian campaigns in America that have actually failed to sustain that case, especially in attempts to exclude science textbooks that do not explicitly promote the biblical account of creation on the grounds that they thereby implicitly promote the 'religion of secular humanism.'

In the case of the Pestalozzi Trust, this organization for home schooling was explicitly linked, not only to a conservative Christian parent organization in the U.S., but also to the work of RJ Rushdoony, the American founder of Christian Reconstructionism. Advocating a literal interpretation of the Bible and a literal adherence to biblical law, Rushdoony inspired the Chalcedon Foundation, the Institute for Christian Economics, the Rutherford Institute, and other right-wing Christian organizations in the United States. Rushdoony was a champion of religious apartheid. 'Segregation or separation,' he wrote, 'is a basic principle of Biblical law with respect to religion and morality' (Rushdoony, 1973:294). In defense of religious apartheid, Rushdoony opposed any form of civil toleration of religious difference, because 'the believer is asked to associate on a common level of total acceptance with the atheist, the pervert, the criminal, and the adherents of other religions as though no differences existed' (Rushdoony, 1973:294). Under the influence of such religious prejudice, Christian Reconstructionists urge South African parents to prevent their children from being exposed to 'foreign' religions, forgetting that those religious and other belief systems are not foreign but flourishing in South Africa.

Disregard for adherents of other religions informs not only theory but also political practice among Christian Reconstructionists. According to a prominent disciple of Rushdoony, Gary North, Christian Reconstructionists are justified in manipulating democratic, constitutional means for Christian ends. 'We must use the doctrine of religious liberty to gain independence for Christian schools,' North wrote, 'until we train up a generation of people who know there is no religious neutrality, no neutral law, no neutral education, and no neutral civil government' (North, 1982:25). Once that programme in Christian religious education was far enough advanced, North declared, then the students it produced would 'get busy constructing a Bible-based social, political, and religious order which finally denies the religious liberty of the enemies of God' (North, 1982:25).

Certainly, Christian Reconstructionism, with its manipulative rhetoric, religious apartheid, and anti-democratic tactics, cannot provide any basis for educational policy in a diverse and democratic South AfricaNevertheless, in the controversy of the new policy for religion and education, most of the media attention given to the new curriculum was framed by the religious agenda of Christian Reconstructionists.

As this brief overview can only suggest, 'fundamentalism' in South Africa has featured in a recurring crisis of authenticity, not only religious authenticity, with its claims on solid foundations in a changing world, but also political authenticity. From the apartheid regime to the democratic dispensation, religious fundamentalism has registered as a force, for better or worse, in relation the stability and legitimacy of the South African state. Against this background, I want to ask: What kind of crisis is 'fundamentalism' currently configuring in our rapidly globalizing and increasingly polarized world? 


\section{Religious Fundamentalism Now}

Since September 2001, we have been under enormous global pressures that have polarized international politics into religious dualisms. As we recall, on 7 October 2001, US President George W Bush, embarking on his military adventure in Afghanistan, issued this polarizing warning, reinforcing his assertion, 'You are either with us or against us.'

Every nation has a choice to make. In this conflict, there is no neutral ground. If any government sponsors the outlaws and killers of innocents, they have become outlaws and murderers, themselves. And they will take that lonely path at their own peril (Lincoln, 2003:100).

On the same day, in response, Osama bin Laden asserted that 'these events have divided the world into two camps, the camp of the faithful and the camp of infidels. May God shield us and you from them' (Lincoln, 2003:103). As historian of religions Bruce Lincoln has observed, these are 'symmetrical dualisms,' mutually reinforcing oppositions, dividing 'us' from 'them,' under God, producing oppositions of both religious and global significance.

Globalization, with its multiple flows, promised new connectivity, new complexity, in fluid, mobile networks, with no centers or peripheries, which would enable people to overcome such polarizing oppositions. Surprisingly, our global terrain is entrenching polarization. We are not immune. In December 2004, a public dispute between President Mbeki and Archbishop Tutu inspired a series of ten installments in ANC Today, 'The Sociology of Public Discourse in a Democratic South Africa,' which began with the polarizing assertion that the people of South Africa 'could not but demand of all and sundry that they should declare where they stand. Inevitably, the question had to be answered brother and sister, whose side are you on!' (Anonymous, 2005a).

So, here we are, poised between the intimacy of kinship, 'brothers and sisters,' and the polarizing imperative to take sides. In our case, the two sides, as formulated by 'The Sociology of Public Discourse,' are the 'elite' and the 'people.' The elite have their 'icons,' like Archbishop Tutu, 'whose opinions must be accepted as being virtually equivalent to the word of a god!' (Anonymous, 2005b). By contrast, the people have their liberation movement, leading the national struggle, which continues, although victory is certain. In the meantime, we find ourselves polarized.

In conclusion, I want to return to my opening observations about defining, theorizing, humanizing, nationalizing, and globalizing religion to suggest some of the reasons we might currently be engaging religious fundamentalism as a crisis within our present historical moment. So, I ask: Why are we worrying about fundamentalism now?

First, in defining fundamentalism, we are confronted with the perennial problem of the very word, 'religion,' operating as an oppositional term. But these oppositions are always situational and relational. In the South African context, moderate Christians might define syncretism as 'too messy' and fundamentalism as 'too pure' in order to situate themselves as 'just right.' Religious conservatives would understandably want to reject the designation, 'fundamentalism,' if it were situated in such a relational calculus. But we have seen religious activists, Christian and Muslim, claiming the designation of fundamentalism in seeking to recover what they regard as religious authenticity. We have also seen them adopting the term, 'fundamentalism,' in pursuing opposition to the apartheid state or the democratic state.

In relation to the modern state, the definition of religion matters, conferring legal recognition, tax exemptions, and other benefits, but also constraining forms of religious life that are denied the status of 'religion' or come into conflict with law and order. Since 2001, 
the issue of defining fundamentalism in South Africa has shifted dramatically from focusing on conservative religious beliefs, in many cases religious beliefs emerging from the United States, to focusing on militant political opposition to the United States. The US State Department has established a basic equivalence between Muslim fundamentalists and terrorists. Looking into South Africa, the US State Department has listed Qibla as a dangerous terrorist organization, a classification that remains in place even though the US State Department's annual International Religious Freedom Report for 2006 noted that 'No Qibla activities were reported in the period covered by this report' (US State Department, 2006). Our efforts at definition, therefore, have to take into consideration these power dynamics of classification.

Second, in theorizing religion, the term, 'fundamentalism,' seems to play the same role in contemporary thought that was filled by the 'primitive' in nineteenth-century evolutionary theories of religion. During the nineteenth century, 'primitives' or 'savages' supposedly displayed superstitious survivals from human prehistory; today, 'fundamentalists' are allegedly reactionary, atavistic adherents of the pre-modern resisting modernity. In both cases, we find thinking about religion situated in developmental theories, whether evolutionnary or modernization theories, in which some people do not seem to be cooperating. They remain behind, as survivals of the pre-modern, or they try to go back, struggling to recover the pre-modern in opposition to modernity.

Theorizing fundamentalism, therefore, is also theorizing the meaning, power, and scope of modernity. On the one hand, modernity is rational. Modern rationality drew upon Enlightenment reason, but it also entailed, as Max Weber taught us, the institutionalized rationalization of power within the modern state and its bureaucratic monopoly and management of coercion over people in a territory. In this respect, the modern horrors of the holocaust or apartheid cannot be dismissed as aberrations in the progressive development of modernity. They were thoroughly rationalized instances of bureaucratic management, efficiency, and control. Fundamentally, therefore, terror can be found at the heart of modernity.

On the other hand, modernity, again following Max Weber, is the disenchantment, or the 'de-magification,' of the world. From this perspective, fundamentalist appeals to archaic tradition appear as atavistic revivals of magic, enchantment, or superstition in the modern world. Perhaps, as Bruno Latour has argued, we have never actually been modern (Latour, 1993). Magic and enchantment linger in the wonders of modern science, the awesome power of the modern state, which is always underwritten by political myths and rituals, and the fetishism of commodities in the capitalist, globalizing market economy. Magic, we might argue, is both shadow and substance of the global economy, shadowed by the 'occult economies' that seek to access wealth through mysteries means (Comaroff and Comaroff, 1999) but given substance by the global orthodoxy of the 'religion of the market' (Loy, 1997).

So, in trying to think about 'fundamentalism' we also have to think about modernity. Religious movements commonly identified as fundamentalist might appeal to pre-modern sources of religious authenticity, but they utilize the most modern communication technology in mobilizing a following. Arguably, they have been at the forefront of postmodern developments in cyberspace, mobile networks, and multi-sited transnational communities. Arguably, some have been at the forefront of postmodern developments in military strategy, with all of its horror, in which suicide bombers, those weaponized human beings (see Hecht, 2003; Martin, 2003; Strenski, 2003), and car bombs, that 'poor man's air force' (Davis, 2006a; 2006b; 2007), have had a definite impact. Theorizing religion, 
therefore, requires wrestling with violence in which both modernity and its discontents are intimately entangled in our world.

Third, with respect to humanizing religion, we see fundamentalism engaged in the most extensive global politics but also in the most intimate sexual politics, gender politics, and family politics. Human beings, as embodied beings, are drawn into this intimate politics. During the 1980s, the self-proclaimed Christian fundamentalist, Jerry Falwell, built his entire political programme on the foundation of such an intimate politics, beginning with 'pro-family' initiatives in opposition to reproductive choices, women's rights, and alternative sexuality. During the first decade of the twenty-first century, we might live in a polarized geopolitical environment, but we also live in a highly-charged intimate politics in which gender, sexuality, and religion are entangled.

As many analysts have observed, religious fundamentalism is obsessed with women's bodies and male power. According to Homa Hoodfor, 'controlling women and their bodies and reclaiming the family as a site of male power and dominance is a common thread found in all brands of fundamentalism' (Hoodfor, 1996; see Gharavi, 2003; Hawley, 1994; Howland, 2003). This gendered politics, however, is not the distinctive creation or sole preserve of religious fundamentalists; it has been a recurring feature of the history of religions. What has changed, in our world, is the new linkages between what Michael Foucault called biopower, the regulation of embodied, gendered, and sexual humanity, and the modern state's demands for conformity and control (see Inda, 2005). Modern states, in their instability, try to enforce controls over this intimate politics of the body as a matter of urgency because they cannot control law and order, shifting foreign relations, or the mysteries and inequities of the global economy. Sex and money, as Roger Friedland has argued, are the basic ingredients of religious fundamentalisms, religious nationalisms, and modern states that must establish an aura of religiosity (Friedland, 2002). Human bodies and national borders, in our current crisis, are threatened. Controls over sexuality, in this reading, mirror attempts to control the promiscuous flows and corruptions of capital in globalizing economic relations. In this respect, pre-modern fundamentalists and modern states are engaged in the same project of intervening in the intimate politics of gender, sexuality, marriage, and human reproduction as ritual substitution for political problems they cannot solve. Intimate politics, therefore, is central not only to religious fundamentalisms but also to modern nations.

Fourth, moving to the national scope of religion, religious fundamentalism suggests that theorists of globalization who declared the 'death of the nation' or the 'death of the state' were premature. Ignoring all predictions of the demise of the nation-state within a transnational, globalizing world, religious fundamentalists have been making claims on state power, struggling to work out their national citizenship in various nations, and challenging any state's monopoly on exercising legitimate violence within or outside a territory. In all of these ways, religious fundamentalists are keeping alive the national question.

Scholars of religion who specialize in religious fundamentalism often identify fundamentalism as primarily a political problem. For example, Almond, Appleby, and Sivan, in their introduction to a global overview of religious fundamentalism, Strong Religion, propose that 'Fundamentalism' is one of the most significant political phenomena of our time' (2003:1; see Aikman, 2003). The importance of this 'phenomenon' only registers as important to the extent that religious actors have either captured or challenged the ultimate power of a modern state. Accordingly, they identify fundamentalists that have seized state power, finding that religious fundamentalists have captured states in five instances since 
1979. 'Since the Iranian revolution, purported fundamentalist movements have risen to the highest levels of power in five countries.' They identify Iran in 1979, Sudan in 1993, Turkey in 1996, Afghanistan in 1996, and India in 1996, 1998, and 1999. Arguably, they might have added a sixth example of religious fundamentalists seizing state power by adding the United States in 2000 to this list, but their point is that religious fundamentalists are significant because they want state power and so they also oppose the power of prevailing states as 'other fundamentalist movements [have] formed powerful and deadly opposition groups' (2003:1).

Opposition groups, in this account, include a diverse array of formations such as Hamas, Al-Qaeda, Sikh extremists, Jewish underground, Armed Islamic Group in Algeria, Islamic revolutionaries in Chechnya, and 'Christian radicals in the United States who stalked feminist activists and gunned down doctors who performed abortions.' Reinforcing their claim that religious fundamentalism is one of the most significant political phenomena of our time, the authors use highly-charged, evocative language to describe how these opposition groups, arguably small and marginal, but allegedly 'powerful and deadly,' have engaged in campaigns in which they 'took up arms,' 'plotted to destroy,' 'assassinated,' 'indiscriminately massacred,' and 'gunned down' their enemies. Opposition groups, of course, should not be doing any of these things. Therefore, these violent acts, religiously motivated, make religious fundamentalism 'one of the most significant political phenomena of our time.' Modern states, which normally do all of these things, whether covertly or overtly, all of the time, do not register in considering the phenomenon of religious violence in our time.

As Rashied Omar has argued, academic analysis of religious fundamentalism, which tends to regard fundamentalism as an inherently oppositional and violent force, has generally neglected the role of institutionalized and even normalized state violence. In his detailed case studies of religious violence in Bosnia, Gujarat, and South Africa, Omar has demonstrated that we must bring state violence into the picture if we hope to understand the 'phenomenon' of violent strategies and tactics by opposition groups. We cannot just single out religious groups that want states or oppose states; we also have to consider the overt and covert violence exercised by states (Omar, 2005).

Finally, in our globalizing world, religious fundamentalism registers as an obstacle to the flows of people, technology, money, new images of human possibility, and new ideals of human solidarity that are in motion, every day, in this changing global landscape. All of this global fluidity, however, is also contradicted by the unilateral and polarizing foreign policy of a US administration promoting a fundamental dualism, insisting that 'you are either with us or against us,' a dualism that is backed up by force.

Critical analysts have pointed to the religious role of the United States - fomenting a variety of religious fundamentalisms during the Cold War, advancing a particular kind of religious fundamentalism in the present - as a crucial agent in our current crisis of fundamentalism. Although we can argue about the historical details, assessing, for example, the extent to which US support for the muhajadeen in Afghanistan created al-Qaeda, we cannot ignore the implication of the United States in the emergence of religious . According to Tariq Ali, 'The most dangerous 'fundamentalism' today - the 'mother of all fundamentalisms' - is American imperialism' (Ali, 2003:xiii).

This global analysis has been echoed from a South African perspective by our poet Dennis Brutus, who surprised an audience of the World Social Forum in Brazil in 2003 when he was asked to speak about religious fundamentalism. In summary, Dennis Brutus identified the major problem in the analysis of religious fundamentalism as the United 
States. Fundamentalism, he argued, 'contrary to the picture that the media portrays, is not so much Muslim fundamentalism as Christian fundamentalist religiosity in the USA! With their special faith in a Jerusalem under Israeli control before the coming Armageddon and rapture of Christians to heaven, these fundamentalists have amassed great influence and power - and have gained a large degree of control over the development and implementtation of US politics and policy-making. This religious fundamentalism is truly one of the most devastating and terrible forms of intolerance, because it demonizes anyone who objects or questions their views and interpretations, naming them heretics and trying to force them - whether one way or the other - into conformity' (Sunday, 2003).

We are worrying about religious fundamentalism now, I propose, because the term configures a crisis that is local, resonating within our national and intimate politics, but it also configures a crisis that is global, everywhere and nowhere, bearing religious significance bordering on the apocalyptic. Religious fundamentalists, as Scott Appleby has suggested, are reactive, selective, absolutist, dualistic, and millenarian. In these terms, here we are, all of us living in fundamentalist scenarios that seem to be made in America.

How do we read the signs of these times? How do we act in relation to this twenty-first century American fundamentalism? In Cape Town, South Africa, an organized criminal gang, the Americans, has developed a distinctive reading of the religious fundamentals of America. Calling their turf and territory in the impoverished townships 'America,' they have rendered 'Americans' into an acronym - All Mighty Equal Rights Is Coming and Not Standing. Proudly displaying the American flag, they have developed a distinctive interpretation of the flag's symbolism by reading the white stripes as money and the red stripes as blood, with blood signifying the violence necessary for making money. According to these Americans in the Cape Flats, therefore, the human truth of the United States is this merger of blood and money (Chidester, 2005:113-15).

Recently, the US Under-Secretary of State for Public Diplomacy, Karen Hughes, reiterated the Bush administration's dualistic worldview by asserting that the world is divided between two opposing 'missions.' In this highly charged religious language, echoing Christian missionary understandings of calling and sending, vocation and submission, confrontation and conversion, Karen Hughes suggested that everyone on the planet lives within an apocalyptic moment poised between death and life. The mission of Islamic terrorists such as Osama bin Laden, she said, 'is a mission of destruction and death; ours a message of life and opportunity’ (cited in Metzler, 2006). If we apply an academic definition of religious fundamentalism, such as Scott Appleby's identification of the reactive, selective, absolutist, dualistic, and millenarian features defining religious fundamentalism, we cannot avoid the conclusion that the United States has been displaying many if not all of these defining characteristics of religious fundamentalism.

South Africa, I am convinced, remains a fruitful place for studying religion. South Africa is also a good place for advancing research and reflection on religious fundamentalism, not because we can place fundamentalism in a South African context but because we can advance South African perspectives on the fundamental problems of the authenticity and legitimacy of the modern state raised by the critical term, 'fundamentalism.' 


\section{BIBLIOGRAPHY}

Aikman, David 2003. 'The Great Revival: Understanding Religious Fundamentalism,' Foreign Affairs 82, 4, http://www.foreignaffairs.org/20030701 fareviewessay15416/ david-aikman/the-great-revival-understanding-religious-fundamentalism.html accessed 27 February 2007.

Ali, Tariq 2003. The Clash of Fundamentalisms: Crusades, Jihads, and Modernity. London: Verso.

Almond, Gabriel A, R Scott Appleby, and Emmanuel Sivan 2003. Strong Religion: The Rise of Fundamentalisms around the World. Chicago: University of Chicago Press.

Anonymous 2003. 'Religions 'Rebuilding SA' Mbeki,' Bua News, 9 September 2003.

Anonymous 2005a. 'The Sociology of Public Discourse in a Democratic South Africa, Part I,' ANC Today 5,2 (14-20 January). http://www.anc.org.za/ancdocs/anctoday/2005/at02.htm, accessed 26 October 2005.

Anonymous 2005b. 'The Sociology of Public Discourse in a Democratic South Africa, Part II, ANC Today 5,3 (21-27 January), http://www.anc.org.za/ancdocs/anctoday/2005/at03.htm accessed 26 October 2005.

Appleby, Scott 2000. The Ambivalence of the Sacred: Religion, Violence, and Reconciliation. Lanham, MD: Rowman and Littlefield.

Arendse, Roger A 1989. 'The Gospel Defence League: A Critical Analysis of a Right Wing Group in South Africa.' Journal of Theology for Southern Africa 69:95-105.

BBC 2005. 'US Chat Show Host Could Be Zulu.'

http://news.bbc.co.uk/2/hi/africa/4096706.stm accessed 26 October 2005.

Chidester, David 1988b. Patterns of Power: Religion and Politics in American. Culture. Englewood Cliffs, NJ: Prentice Hall.

Chidester, David 1992a. Shots in the Streets: Violence and Religion in South Africa. Cape Town: Oxford University Press.

Chidester, David 1996. Savage Systems: Colonialism and Comparative Religion in Southern Africa. Charlottesville: University Press of Virginia.

Chidester, David 2000a. Christianity: A Global History. San Francisco: Harper Collins.

Chidester, David 2000b. 'Mapping the Sacred in the Mother City: Religion and Urban Space in Cape Town, South Africa.' Journal for the Study of Religion 13, 1-2: 5-41.

Chidester, David 2002. 'Credo Mutwa, Zulu Shaman: The Invention and Appropriation of Indigenous Authenticity in African Folk Religion.' Journal for the Study of Religion 15,2: 65-85.

Chidester, David 2003. 'Religion Education in South Africa: Teaching and Learning about Religion, Religions, and Religious Diversity,' British Journal of Religious Education 25, no. 4: 261-278.

Chidester, David 2004. 'Classify and Conquer': Friedrich Max Müller, Indigenous Religious Traditions, and Imperial Comparative Religion,' in Jacob K. Olupona, ed., Beyond Primitivism: Indigenous Religious Traditions and Modernity. London and New York: Routledge, 71-88.

Chidester, David 2005. Authentic Fakes: Religion and American Popular Culture. Berkeley: University of California Press.

Christian Centre 2001. Views on the Draft Curriculum 2005 Statements. www.cellchurchonline.com/downloads/views_on_the_new_curriculum.doc accessed 12 January 2002. 
Comaroff, Jean, and John L Comaroff 1999. 'Occult Economies and the Violence of Abstraction: Notes from the South African Postcolony.' American Ethnologist 26:279-303.

Concerned Evangelicals 1986. Evangelical Witness in South Africa: A Critique of Evangelical Theology and Practice by Evangelicals Themselves. Dobsonville, South Africa:

Davis, Mike 2006s. 'The Poor Man's Air Force: A History of the Car Bomb (Part 1).' TomDispatch (12 April 2006). http://www.tomdispatch.com/index.mhtml?pid=76140, accessed 26 February 2007.

Davis, Mike 2006b. 'Car Bombs with Wings: A History of the Car Bomb (Part 2).' TomDispatch (14 April 2006), http://www.tomdispatch.com/index.mhtml?pid=76824, accessed 26 February 2007.

Davis, Mike2007. Buda's Wagon: A Brief History of the Car Bomb. London: Verso.

Esack, Farid 1988. 'Three Islamic Strands in the South African Struggle for Justice.' Third World Quarterly 10,2:473-498.

Friedland, Roger 2002. 'Money, Sex and God: The Erotic Logic of Religious Nationalism.' Sociological Theory 20,3:381-425.

Gharavi, Tina 2003. 'Veiled Societies/Hidden Sexualities: Investigating and Documenting Gender and Public Space in Tehran, Iran, and Buffalo, NY.' Zivot Umjetnosti. http://www.hart.hr/pdf/zu70/gharavi.pdf, accessed 25 February 2007.

Gifford, Paul 1988. The Religious Right in Southern Africa. Harare: University of Zimbabwe.

Gifford, Paul 1991. The New Crusaders: Christianity and the New Right in Southern Africa. London: Pluto Press.

Green, Pippa 1987. 'Apartheid and the Religious Right.' Christianity and Crisis 47,14:32628.

Hawley, John Stratton 1994. Fundamentalism and Gender. Oxford: Oxford University Press.

Hecht, Richard D 2003. 'Deadly History, Deadly Actions, and Deadly Bodies: A Response to Ivan Strenski's 'Sacrifice, Gift, and the Social Logic of Muslim 'Suicide Bombers',' Terrorism and Political Violence 15,3:35-47.

Hoodfar, Homa1996. 'Bargaining with Fundamentalism: Women and the Politics of Population Control in Iran.' Reproductive Health Matters 8:30-40. http://www.hsph.harvard.edu/Organizations/healthnet/gender/docs/hoodfar.html, accessed 25 February 2007.

Howland, Courtney W (ed.) 2001. Religious Fundamentalisms and the Human Rights of Women. London: Palgrave Macmillan.

Inda, Jonathan Xavier (ed.) 2005. Anthropologies of Modernity: Foucault, Governmentality, and Life Politics. London: Blackwell.

Latour, Bruno. 1993. We Have Never Been Modern. Trans. Catherine Porter. Cambridge, Mass.: Harvard University Press.

Lehmann, Uta. 2006. 'The Impact of the Iranian Revolution on Muslim Organizations in South Africa during the Struggle against Apartheid.' Journal for the Study of Religion 19,1:23-39.

Le Roux, CJB and HW Nel 1998. 'Radical Islamic Fundamentalism in South Africa: An Exploratory Study. Journal for Contemporary History 23,2: 
Lincoln, Bruce 2003. Holy Terrors: Thinking about Religion after September 11. Chicago: University of Chicago Press.

Loy, David R 1997. 'Religion of the Market.' Journal of the American Academy of Religion 65:275-290.

Mandela, Nelson 1999. 'Address by President Nelson Mandela to Parliament, 5 February 1999.'

Martin, Richard C 2003. 'Ivan Strenski's Analysis of Human Bombers: A Response.' Terrorism and Political Violence 15,3:48-56.

Metzler, John 2006. 'Karen Hughes' Mission: Explaining America Abroad,'World Tribune.com (19 May 2006). http://www.worldtribune.com/worldtribune/WTARC/2006/mz5_19.html, accessed 25 February 2007.

North, Gary. 1982. 'The Intellectual Schizophrenia of the New Christian Right.' Christianity and Civilization 1:1-40.

Omar, A Rashied 2005. Religion, Violence, and the State: A Dialogical Encounter between Scholars and Activists. Doctoral thesis, University of Cape Town.

Pandor, Naledi 2005. 'Address by the Minister of Education, Naledi Pandor, MP, at the World Halaal Council AGM, Civic Centre, Cape Town, 13 September 2005.' http://www.info.gov.za/speeches/2005/05091616151001.htm, accessed 26 October 2005.

Rice, Desmond C 1987. Islamic Fundamentalism as a Major Religiopolitical Movement and its Impact on South Africa. M.A. thesis, University of Cape Town.

Rushdoony, R. J. 1973. The Institutes of Biblical Law. Nutley, N.J.: Craig Press.

Sherman, Jacob 2005. Summary for the September 4 to 9, 2005 Islamic Fundamentalism Conference Hosted by Esalen's Center for Theory and Research (CTR). http://www.esalenctr.org/display/fund_sherman.cfm, accessed 26 February 2007.

Stones, Christopher R 1977. 'The Jesus People: Changes in Security and Life-Style as a Function of Non-Conformist Religious Influence.' Journal of Social Psychology 97:127-33.

Stones, Christopher R 1978a. 'The Jesus People: Fundamentalism and Changes in Factors Associated with Conservatism.' Journal for the Scientific Study of Religion 17,2:155-58.

Stones, Christopher R 1978b. 'Fundamentalism and Conservatism among Jesus People in South Africa.' Journal of Psychology 98:225-29.

Strenski, Ivan 2003. 'Sacrifice, Gift, and the Social Logic of Muslim 'Suicide Bombers.', Terrorism and Political Violence 15,3:1-34.

Sunday, Lisa Marie Laegreid 2003. 'Struggling against Fundamentalism and Intolerance,' http://southafrica.indymedia.org/news/2003/01/2931.php, accessed 31 October 2006.

Tayob, Abdulkader I 1996. 'Jihad against Drugs in Cape Town: A Discourse-Centred Analysis.' Social Dynamics 22,2:23-29.

US State Department 2006. International Religious Freedom Report 2006: South Africa. http://www.state.gov/g/drl/rls/irf/2006/71325.htm, accessed 22 February 2007. 